\title{
Occurrence of Toxoplasma gondii antibodies in lowland tapirs maintained ex situ in Brazil and Paraguay
}

\author{
Maria Fernanda Naegeli Gondim ${ }^{1}$ Igor da Cunha Lima Acosta ${ }^{2}$ Maria Cristina Valdetaro Rangel $^{1}$ \\ Herbert Sousa Soares ${ }^{2}$ Solange Maria Gennari ${ }^{2}$ Jitender Prakash Dubey ${ }^{3}$ \\ Zalmir Silvino Cubas ${ }^{4}$ Wanderlei de Moraes $^{4}$ Francisco Javier Sosa Chaparro $^{5}$ \\ Francisco Candido Cardoso Barreto ${ }^{6}$ João Luiz Rossi Junior ${ }^{*}$
}

${ }^{1}$ Departamento de Medicina Veterinária, Universidade de Vila Velha (UVV), 29102-606, Vila Velha, ES, Brasil. E-mail: joao.rossi@uvv.br. "Corresponding author.

${ }^{2}$ Departamento de Medicina Veterinária Preventiva e Saúde Animal, Faculdade de Medicina Veterinária, Universidade de São Paulo (USP), São Paulo, SP, Brasil.

${ }^{3}$ United States Department of Agriculture, Agricultural Research Service, Beltsville Agriculture Research Center, Animal Parasitic Diseases Laboratory, Beltsville, MD, USA.

${ }^{4}$ Refúgio Biológico Bela Vista, Itaipu Binacional, Foz do Iguaçu, PR, Brasil.

${ }^{5}$ Centro de Investigación de Animales Silvestres (CIASI), Itaipu Binacional, Hernandárias, Alto Paraná, Paraguay.

${ }^{6}$ Laboratório de Ecologia Quantitativa, Departamento de Ciências Biológicas, Universidade Federal do Espírito Santo (UFES), Vitória, ES, Brasil.

ABSTRACT: Lowland Tapir (Tapirus terrestris) is the second largest South American land mammal. It is strictly herbivorous and its exposure to Toxoplasma gondii should be indicative of environmental contamination by oocysts.In the present study antibodies to T. gondii in 47 Brazilian tapirs maintained ex situ in 10 Brazilian and in one Paraguayan institution were sought in serum samples by the modified agglutination test $(M A T \geq 25)$. None of the animals presented clinical signs during the study. From 47 animals 35 (74.5\%) were positive with titers of 25 in 8, 50 in 6, 100 in 12, 200 in 5, 400 in 1 and 800 in 3. One animal had samples collected on twice, and 19 were born in captivity. There was no association between occurrence of $\boldsymbol{T}$. gondii antibodies and gender, and positive animals were reported in all institutions. The high occurrence of seropositive tapirs born ininstitutions (54.3\%) confirmed the high exposure of these mammals to T. gondii in captivity. Only two cases ofabortion were reported, but it was not possible to correlate these abortions to T. gondii infection. Key words: Ex situ, lowland tapir, Tapirus terrestris, Toxoplasma gondii, seroprevalence.

Ocorrência de anticorpos para Toxoplasma gondii em antas brasileiras mantidas ex situ no Brasil e no Paraguai

RESUMO: A anta brasileira (Tapirus terrestris) é o segundo maior mamífero terrestre da América do Sul. É estritamente herbívora e sua exposição ao Toxoplasma gondii indica contaminação ambiental por oocistos. No presente estudo, 47 antas brasileiras mantidas ex-situ, em 10 instituições brasileiras e em uma paraguaia, tiveram amostras de soro avaliadas para a presença de anticorpos para $\mathbf{T}$. gondii pelo Teste

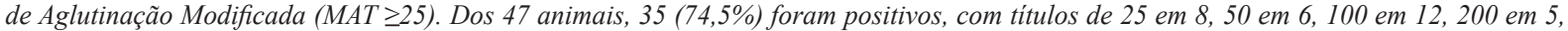
400 em 1 e 800 em 3 animais. Um animal teve amostras coletadas em duas ocasiões e, 19 nasceram em cativeiro. Não houve associação entre ocorrência de anticorpos para T. gondii e gênero e, animais positivos foram encontrados em todas as instituições. A alta ocorrência de antas soropositivas nascidas nas instituições (54,3\%) confirma a alta exposição desses mamíferos para T. gondii em cativeiro. Apenas dois casos de aborto foram relatados, porém, não foi possível correlacioná-los à infecção pelo T. gondii.

Palavras-chave: Anta brasileira, Ex situ, Tapirus terrestris, Toxoplasma gondii, seroprevalência.

The protozoan parasite Toxoplasma gondii infects virtually all endothermic animals, including humans (DUBEY, 2010). Felids, both domestic and wild, are the only known definitive hosts, and the other endothermic animals are considered intermediate hosts and can become infected through ingestion of water or food contaminated by oocyts or by eating tissue cysts containing the parasite bradyzoites (DUBEY, 2010).

Tapirus terrestris, known as Brazilian tapir or lowland tapir, is the second largest South American land mammal (EISENBERG \& REDFORD, 1999) and has the widest distribution. T. terrestris is exclusively herbivorous, and is listed as vulnerable to extinction, according to the International Union for Conservation of Nature (FURTADO et al., 2010; NAVEDA et al., 2011).

High prevalence of anti-T. gondii antibodies have been detected in zoo animals around the world (SILVA et al, 2001; DE CAMPS et al 2008). Although few data on the infection by the parasite in tapirs is available, the modified agglutinating test (MAT) has already been used to identify antibodies 
in captive and free-living individuals of this species (NAVEDA et al., 2011). In this study the presence of $\boldsymbol{T}$. gondii antibodies was determined in T. terrestris kept ex situ in institutions located in Brazil and Paraguay.

Between November 2010 and December 2012, T. terrestris from 10 Brazilian and one Paraguayan institution had blood samples collected. In total, samples were obtained from 47 tapirs (18 adult females, one sub-adult female, one juvenile female, 19 adult males, three sub-adult males and five juvenile males). Individuals were separated in juvenile (6 months to 1 year), sub-adult (1-4 years), and adult (over 4 years of age) according known age or estimations via tooth wear and appearance of foot cushions and corporal measurements (MEDICI, 2010) One animal had blood samples collected on two occasions (November 2010 and October 2011).Eight institutions were located in the southeastern region of Brazil (São Paulo, Minas Gerais and Espírito Santo States) and two in the southern region of Brazil (Paraná State). The Paraguayan institution is located in the Alto Paraná region.

Blood samples $(10-50 \mathrm{~mL})$ were collected using puncture of a saphenous or cephalic vein or in their carpal/tarsal derived, in the medial access. Serum was separated by centrifugation and kept at $-20^{\circ} \mathrm{C}$ until analysis.

Sera were processed using MAT at cut-off 1:25 and those positive were diluted base two, until the final titer. Positive and negative controls, previously known, were adopted (FURTADO et al., 2010; MINERVINO et al., 2010). The association between gender, age and the presence of $\boldsymbol{T}$. gondii antibodies was analyzed using the chi-square test with Yates correction, and $\mathrm{P}<0.05$ were considered significant. To assess the relation of age on the presence or absence of $\boldsymbol{T}$. gondii antibodies, was applied a logistic regression on the data after transforming them in zeros and ones. For statistical purposes, the animal that had blood samples collected in two occasions, just the second collection was taken into consideration. All the analyses were performed on the $\mathrm{R}$ software version 3.3.1 (R CORE TEAM, 2016).

Antibodies against $T$. gondii $(\mathrm{MAT} \geq 25)$ were reported in $74.5 \%$ (35/47) tapirs (Table1). The highest titer was 800 , reported in three animals. Antibodies were detected in $75 \%$ of females $(15 / 20)$ and $74.1 \%$ of males $(20 / 27)$. No correlation was observed between gender and presence of $\boldsymbol{T}$. gondii antibodies. Concerning age, 30 out of 37 adults $(81.1 \%)$, two out of the four sub-adults $(50 \%)$ and three out of the six juveniles animals $(50 \%)$ showed titer $\geq 25$. No relationship between age on presence or absence of $\boldsymbol{T}$. gondii antibodies was reported $(\mathrm{P}=0.152)$. This reinforces the hypothesis that the simple exposure of animals to oocysts is a determinant factor of this contamination. T. gondii positive animals were reported in all assessed institutions. The animal that was assessed in two occasions was negative in the first collection (November 2010) and had a titer of 50 in the second (October 2011), indicating that infection occurred between collections.

Although the presence of antibodies against T. gondii had already been reported in tapirs (ZHANG et al., 2000; FURTADO et al., 2010; MINERVINO et al., 2010) this is the first study with a large sampling space and involving animals from different locations. The transmission of $\boldsymbol{T}$. gondii in zoos is extremely important, because resistant and highly sensitive species to T. gondii, to which the disease can be fatal, are living in the same environment (DE CAMPS et. al., 2008). All 47 assessed tapirs were reported in good health conditions on clinical examination, even the three animals that had the highest titer (800), suggesting that in this species the infection probably occurs asymptomatically, as observed in most affected species (DUBEY \& JONES, 2008).

Two female tapirs, with titers of 100 and 50 , had given birth to healthy pups one and three months before tested, respectively. However, two other females, with titers of 25 and 800 , had a recent miscarriage history. Although T. gondii is associated with congenital infection and abortion (DUBEY $\&$ JONES, 2008), there are no studies associating reproductive losses to $\boldsymbol{T}$. gondii infection in this animal species.The MAT employed here detected $\mathrm{IgG}$ antibodies and seropositivity indicated exposure to the parasite. Although MAT has not been validated in tapirs, a MAT titer of 1:25 is considered as one of the most sensitive and specific tests for toxoplasmosis in animals (DUBEY \& JONES, 2008).

Similar occurrence values were detected in females $(75 \%)$ and male $(74.1 \%)$ animals, comparable to observations also made in other studies with wild animals, what indicated that animals of both sexes are equally exposed to $\boldsymbol{T}$. gondii. (SILVA et al., 2001; CARME et al., 2002; MINERVINO et al., 2010).

Nineteen out of $35(54.3 \%)$ positive animals were born at the institution where the collection was performed, confirming that the infection occurred in this environment. It could reflect an error in the institutional management, facilitating the contact with oocysts by the environment, food, or water (ANDRÉ et al., 2010). It was not possible to determine the sources of infection but the high 
Table 1 - Institutions, location and number of Tapirus terrestris sampled and positive to the presence of antibodies to T. gondii.

\begin{tabular}{|c|c|c|}
\hline Institution & Location City/State & N. positive/ N. examined (\%) \\
\hline 1 & Campinas/SP & $1 / 2(50.0)$ \\
\hline 2 & Sorocaba/SP & $2 / 6(33.3)$ \\
\hline 3 & Bauru/SP & $1 / 1(100.0)$ \\
\hline 4 & São Bernardo do Campo/SP & $2 / 2(100.0)$ \\
\hline 5 & Tapiraí/SP & $2 / 2(100.0)$ \\
\hline 6 & Marechal Floriano/ES & $2 / 4(50.0)$ \\
\hline 7 & Cachoeiro do Itapemirim/ES & $2 / 2(100.0)$ \\
\hline 8 & Poços de Caldas/MG & $1 / 1(100.0)$ \\
\hline 9 & Foz do Iguaçu/PR & $2 / 2(100.0)$ \\
\hline 10 & Foz do Iguaçu/PR & $4 / 6(66.7)$ \\
\hline 11 & Hernandarias/AP & $16 / 19(84.2)$ \\
\hline Total & & $35 / 47(74.5)$ \\
\hline
\end{tabular}

exposure in tapirs is probably associated with the ingestion of oocysts present in the feed, water or pasture provided, since tapirs are strict herbivores and diet in captivity is usually based on horse feed, forage, grains, fruits and vegetables (CLAUSS et al., 2009). Most of these foods provided and pasture can easily be contaminated by feral cat feces or by mechanical transportation of oocysts shed by captive wild felids and passed through keeper's clothing, boots, cleaning equipment or by transport hosts as birds and insects (ANDRÉ et al., 2010). So it is very important acquire and store feed carefully, as control the existence of feral cats in the zoo vicinities, preventing food and environmental contaminations (DE CAMPS et al., 2008). T. gondii oocysts are highly resistant, and to the routine, there is no easy and convenient method to kill them on fruits and vegetables, other than cooking until the temperature reaches $60^{\circ} \mathrm{C}$ (DE CAMPS et al., 2008).

The authors would like to thank the Foundation for Research Support of the Espírito Santo (FAPES - Processes 50239368 and 54684137), and the staff of all the sampled Institutions for their support during collection. We also thank Drs. A. Marcili, L. F. Tobias, P. R. Mangini, R. C. Santos, and E. R. Monteiro for their support in the development of this research.

\section{BIOETHICS AND BIOSSECURITY COMMITTEE APPROVAL}

All procedures were performed under the license number 34372-1, from the Brazilian Institute of Environment and
Renewable Natural Resources (IBAMA) and the approval number 175-2011 from the Committee of Ethics in the Use of Animals of Universidade de Vila Velha (CEUA-UVV)

\section{REFERENCES}

ANDRÉ, M.R. et al. Antibodies to Toxoplasma gondii and Neospora caninum in Captive Neotropical and Exotic Wild Canids and Felids. Journal of Parasitology, v.96, p.10071009, 2010. Available from: <https://www.ncbi.nlm.nih.gov/ pubmed/20950109>. Accessed: Oct. 16, 2016. doi: 10.1645/ GE-2502.1.

CARME, B. et al. Serologic survey of Toxoplasma gondii in noncarnivorous free-ranging neotropical mammals in French Guiana. Vector Borne Zoonotic Disease, v.2, p.1117, 2002. Available from: <http://online.liebertpub.com/doi/ab s/10.1089/153036602760260733>. Accessed: Mar. 11, 2016. doi: $10.1089 / 153036602760260733$.

CLAUSS, M. et al. Diet composition, food intake, body condition, and fecal consistency in captive tapirs (Tapirus spp.) in UK collections. Zoo Biology, v.27, p.1-13, 2009. Available from: $<$ http://www.ncbi.nlm.nih.gov/pubmed/19681143>. Accessed: Mar. 12, 2016.doi: 10.1002/zoo.20225.

DE CAMPS, S.J. et al. Seroepidemiology of Toxoplasma gondii in zoo animals in selected zoos in the Midwestern United States. Journal Parasiltology, v.94, p.648-653, 2008. Available from: $<$ https://www.ncbi.nlm.nih.gov/pubmed/18605803>. Accessed: Mar. 11, 2016.doi:10.1645/GE-1453.1.

DUBEY, J.P. Toxoplasmosis of animals and humans. 2.ed. Boca Raton (FL): CRC,2010, 336p.

DUBEY, J.P., JONES, J.L. Toxoplasma gondii infection in humans and animals in the United States. International Journal for Parasitology, v.38, p.1257-1278, 2008. Available from: <https:// www.ncbi.nlm.nih.gov/pubmed/18508057>. Accessed: Oct. 16,2016.doi: 10.1016/j.ijpara.2008.03.007. 
EISENBERG, J.F.; REDFORD, K.H. Mammals of the neotropics: the central neotropics. Ecuador, Peru, Bolivia, Brazil. Chicago (IL): The University of Chicago, 1999, 610p.

FURTADO, M.M. et al. Serologic survey for selected infectious diseases infree-ranging Brazilian tapirs (Tapirus terrestris) in the Cerrado of central Brazil. Journal of Zoo andWildlife Medicine, v.4, p.133-136, 2010. Available from: <http://www. zoowildlifejournal.com/doi/pdf/10.1638/2007-0087.1>. Accessed: ago. 11, 2016. doi: 10.1638/2007-0087.1.

MEDICI, E.P. Assessing the viability of lowland tapir populations in a fragmented landscape. 2010.276f. (Ph.D. thesis), -Durrel Institute of Conservation and Ecology (DICE), University of Kent.

MINERVINO, A.H.H. et al. Seroprevalence of Toxoplasma gondii antibodies in captive wild mammals and birds in Brazil. Journal of Zoo and Wildlife Medicine, v.41, p.572-574, 2010. Available from: <http://www.zoowildlifejournal.com/doi/pdf/10.1638/20100046.1>. Accessed: Mar. 11,2016.doi: 10.1638/2010-0046.1.
NAVEDA, A. et al. Tapirus terrestris. In: IUCN 2011. IUCN Red List of Threatened Species [internet]. 2011. Available from: $<$ http://www.iucnredlist.org/>. Accessed: Nov. 15, 2016.

R CORE TEAM R: alanguage and environment for statistical computing.Viena: R Foundation for Statistical Computing, 2016. Available from: <https://www.r-project.org/>. Accessed: Nov. $15,2016$.

SILVA, J.C.R. et al. Seroprevalence of Toxoplasma gondii in captive neotropical felids from Brazil.Veterinary Parasitology,v.102, p.217-224,2001. Available from: <http://www.sciencedirect.com/ science/article/pii/S0304401701005234>. Accessed: Mar. 11, 2016. doi: 10.1016/S0304-4017(01)00523-4.

ZHANG, S.Y. et al. Prevalence of antibodies to Toxoplasma gondii in the sera of rare wildlife in the Shanghai Zoological Garden, People's Republic of China. Parasitology International, v.49, p.171-174, 2000. Available from: <http://www.sciencedirect. com/science/article/pii/S1383576900000416>. Accessed: Mar. 11, 2016. doi: 10.1016/S138-5769(00)00041-6. 